УДК 294

ББК $86.35-2$

DOI 10.31554/2222-9175-2021-43-114-125
А. М. Аонец
ТУГАН АОБСАН ЧОКЬИ НИМА. ХРУСТААЬНОЕ ЗЕРЦА О

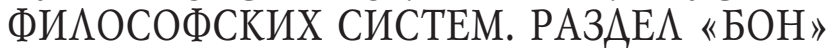 (перевод с тибетского и комментарий)

В работе представлен перевод раздела тибетоязычного сочинения известного буддийского ученого монаха традиции Гелук из провинции Амдо Тугана Лобсана Чокьи Нимы (тиб. Thu'u bkwan blo bzang chos kyi nyi ma, 1737-1802), посвященного изложению истории и воззрений тибетской традиции Бон. В разделе рассматривается история Бон в целом, а также трех таких его видов, как 1) первоначальный Бон; 2) ошибочный Бон и 3) трансформированный Бон. Рассматривается учение Бон и определяется его специфика в отношении воззрения, методов созерцания и т. д. Перевод выполнен по изданию: Thuu bkwan. Grub mtha' bzhugs so. - 'Bras spungs blo gsal gling dpe mdzod khang, 1992.

Ключевые слова: история Тибета, Бон, тибетская философия, сиддханта, тибетская доксография, буддизм.

\title{
A. M. Donets \\ THUKEN LOBSANG CHÖKYI NYIMA. THE CRYSTAL MIRROR OF PHILOSOPHICAL SYSTEMS. "BÖN" SECTION (translation from Tibetan and commentary)
}

This work is a translation of a section of the Tibetan language composition of Thuken Lobsang Chökyi Nyima (Tib. Thu'u bkwan blo bzang chos kyi nyi ma, 1737-1802), a famous Buddhist scholar-monk of the Gelug tradition from the province of Amdo. The section examines the history of Bon as a whole, as well as three types: 1) emergent Bön; 2) deviant Bön; and 3) transformed Bön. The Bönpo teaching system is examined and its special features are identified in relation to points of view, methods of contemplation, etc. The translation was completed according to the edition: Thuu bkwan. Grub mtha 'bzhugs so. - 'Bras spungs blo gsal gling dpe mdzod khang, 1992.

Keywords: history of Tibet, Bön, Tibetan philosophy, Siddhanta, Tibetan doxography, Buddhism.

$\prod$ редлагаемая вниманию читателя работа - перевод главы авторитетного (история философских систем). Обычно работы этого жанра представляют собой анализ (с философской позиции той или иной школы буддизма) системы философских воззрений, выработанных в Индии [Нестеркин 2014]. Классическими трактатами здесь являются работы Чанкья Рольбидорже и Жамьяна Шепы. Текст Тугана существенно отличается от них и по своей структуре, и по задачам, которые автор в нем решает. Системам индийской буддийской философской мысли в нем уделено достаточно скромное место - только одна глава, перевод которой мы уже представили читателю [Донец 2021]. Основное место в работе занимает анализ религиозно-философских воззрений школ собственно тибетского буддизма, учения ти-

ДОНЕЦ Андрей Михайлович - доктор исторических наук, ведущий научный сотрудник Федерального государственного бюджетного учреждения науки Институт монголоведения, буддологии и тибетологии СО РАН (г. Улан-Удэ, Россия). E-mail: sn3716@yandex.ru. 
бетской традиции Бон, а также учения буддийских и небуддийских школ Китая и Монголии. Другой особенностью работы Тугана, по сравнению с классическими сиддхантами, является наличие разделов, описывающих историю самих этих школ, а не только их философских доктрин. Это делает сиддханту Тугана уникальным источником по буддийской компаративистике и истории буддизма, преломленной через призму воззрений традиции Гелук, к которой принадлежал автор.

\section{Раздел «Бон»}

Расскажу историю известной как Бон системы Шена [I],

Пришедшей заранее во мрак Тибета как посланница-заря,

Подготавливая широкий путь появлению

Света солнца - высшего Учения [II].

\section{1. История системы Бон}

В [одном] бонском тексте сказано: «В [тот период] этой кальпы, [в течение которого продолжительность] жизни [человека постепенно сокращается] от неизмеримого [числа] лет до 10 [III], [должны по очереди] являться 18 высших Господ Учителей - от Кюнсана [IV] до Тонма Медона» [V]. Поэтому Шенраб, явившийся в то время, [когда продолжительность] жизни [человека достигает] 100 лет, является бонским Учителем теперешнего [периода].

Итак, Шенраб Мивоче появился в Длинной долине Олмо страны Шаншун [VI]. Кое-кто говорит, что он - волшебное явление [VII] Будды. Говорят также: «Появился одновременно с нашим Учителем (Буддой)». В «Белой вайдурье» [VIII] имеются [следующие слова]:

Решив воспитывать [людей в духе] Бон [IX],

Явился чудесно как Шенраб Миво в стране Шаншун,

Совершил 12 деяний Бон,

Объяснил девять ступеней - Колесниц,

Открыл двери богов [для] живых,

Закрыл двери кладбища [для] мертвых,

Установил существ на путь юндрун [X].

Как бы там ни было, известно, что некто, обладающий сверхъестественными способностями (абхиджня), волшебными силами (риддхи) и другими достоинствами, посещал это место теперешнего расположения факультета (дацана) [в] Арие «Онда Сэрхан Цэ» [XI], гору Ринчен Пунпа [XII], гору Бон к востоку от храма Бучу [в] стране Кон [XIII] и другие места в Тибете, усмирил и привел к покорности множество могучих божеств мира. Он изложил четыре раздела учения юндрун [Бона], пятый - сокровищницу [XIV] и т. д. Во множестве появились его последователи: Дунцоба Муцо Дэмдруг [XV], мудрецы [из страны] Тасиг - Муца Тра Хэсэ, Титог Барцам, Гухили Парма [XVI], индийский мудрец Лхадаг Агдро, китайский мудрец Легтан Манпа [XVII], мудрец [из страны] Том - Сэрог Чечжам [XVIII], тибетский мудрец Демгьин Цамэгэ [XIX], мудрец [из страны] Миньяг - Чеца Гаргу [XX], мудрец [из страны] Бумпа - Мупун Сантан [XXI], мудрец из Шаншуна - Шара Бучен [XXII] и др. Поэтому учение Бон распространилось и стало культивироваться во всех странах.

2. Истории разных [видов] Бона

В [описании истории] распространения Бона в Тибете - три [раздела]:

2.1. Первоначальный Бон.

2.2. Ошибочный Бон.

2.3. Трансформированный Бон [XXIII].

2.1. Первоначальный Бон

Во время [правления] Тидэ Цэнпо - шестого в династии [тибетских царей, начавшейся] с Няти Цэнпо [XXIV], - некий тринадцатилетний ребенок из рода Шен 
в Уе, или «Шолон» [XXV], был уведен духом и в течение 13 лет [жил среди духов] во всех областях Тибета. А в 26 лет [он снова] появился среди людей. Обладая способностями духов, являл разнообразные познания, говорил, что поскольку в такой-то и такой-то стране имеются такие-то и такие-то божества и духи, [которые] приносят такую-то пользу и такой-то вред, то благодаря таким-то жертвенным молениям $[\mathrm{XXVI}]$ и поднесению им [таких-то ритуальных предметов] «яйтаг» [XXVII] будет польза. Говорил, что при 26 [царях этой] династии, [т. е.] от Няти Цэнпо до Титог Чжецэна [XXVIII], государство будет под покровительством Бона.

Хотя это нигде и не подтверждается, но, очевидно, впервые Бон появился в Тибете именно тогда. Однако в Боне тех времен было только подавление [обитающих] внизу [духов] дре и сри, поднесение жертв [пребывающим] вверху древним божествам и чтение [ритуалов в связи с] домашним очагом в середине [XXIX], и не было [даже] терминов, [относящихся к] воззрениям и т. д. системы Бон. Поэтому в некоторых [сочинениях по] истории религии и династийных хрониках указывается, что Бон начал распространяться со времен [тибетского царя] Дигум Цэнпо $[\mathrm{XXX]}$. Его также называют «Боном-причиной», [или Боном] «черной воды» $[\mathrm{XXXI}]$.

\section{2. Оиибочный Бон}

Не зная, [как сделать обряд] «диши» [XXXII] для царя Дигум Цэнпо, тибетские бонпо позвали для [совершения ритуала] «диши» трех бонпо - из Кашмира, Бруша [XXXIII] и Шаншуна. Первый, опираясь на реализацию гегонкью [XXXIV] и божества огня, передвигался в небе на бубне, делал кровопускание [XXXV], являл способность разрубать железо птичьим пером и т. д. Второй указывал благоприятное и неблагоприятное благодаря бросанию жребия из разноцветных ниток, [прорицанию] «слова бога», исследованию обожженных [бараньих] лопаток [XXXVI] и другим видам гадания. Третий знал [ритуалы] шинпо дурва [XXXVII], ди дулва [XXXVIII] и другие виды некромантии - шид [XXXIX]. Говорят, что [именно тогда] с Боном смешалась ошибочная система (сиддханта) тиртиков-ишвараитов [XL].

2.3. Трансформированный Бон

[Было] три [трансформации].

Первая трансформация имела место, когда пандида Шамтаб Онпочен [XLI] поместил ложное учение в «клад» [XLII], а потом сам же достал [и оно] и смешалось с Бон.

Вторая (средняя) трансформация. Во времена [царя] Тисрон Дэцэна [XLIII] был издан указ [о том, что] бонпо должны переходить в Учение, говорящее о Просветлении Победителя (Будды). Прослушав Учение о высшей Драгоценности [XLIV], они не пожелали [сами перейти]. Поскольку был нарушен приказ царя, то он разгневался. [Тогда они] превратили в бонские некие [тексты] канона Будды, соединив с [учением] Бон. Услышав об этом, царь приказал казнить превративших Канон Татхагаты (Будды) в бонский. И поскольку многие были казнены, то бонпо испугались и спрятали трансформированные [тексты] вместе с добавлениями в потайном месте, а впоследствии достали. Говорят, что [это] и является «кладом Бон» [XLV].

Третья - трансформация конечная. После того, как [царь] Ландарма [XLVI] coкрушил религию [Будды в Тибете], некто по имени Шенгур Луга [XLVII] из Цзан Ньян То [XLVIII] переделал в [духе учения] Бон много [содержащих] Слово Будды [текстов] в неком бонском месте Дар Юл До Лаг [XLIX], что в Уе. Большой Юм $[\mathrm{L}]$ стал называться «Кхамчен» [LI], двадцатипятитысячная [Сутра Праджня-парамиты] - «Кхамчун» [LII], «Объяснение» [LIII] - «Бондо» [LIV], «Пять дхарани» [LV] - «Лубум гарнаг» [LVI]. Были введены разные новые термины и несходные c [буддийским] Учением [трактовки] смысла. [Эти тексты] спрятали у скалы Цо-а Дрэучун [LVII], а потом сами же и достали. Впоследствии некоторые лидеры Бона и др. делали много аналогичных трансформаций. 
Эти три [вида] трансформированного Бона - предшествующий, средний и последующий - называют «Боном-плодом» и [Боном] «белой воды» [LVIII].

\section{3. Учение Бона}

В системе Бона есть некий аналог Ганжура.

Тексты, объясняющие взгляд: «Золотые четки драгоценной реализации», «Бритва ветра, связанного с корнем», «Ясный свет колеса наставлений» [LIX] и др.

Тексты о созерцании: «Раздел девяти капель самотрансформации скандх», «Золотая капля», «Переживание тела и ума», «Белый трон объяснения сознания» [LX] и др.

Раздел деяния: «Сто тысяч объяснений восьми дхату», «Сто тысяч смыслов установленного изначальным жрецом», «Сто тысяч путей десяти ступеней счастья», «Сто тысяч дисциплин совершенно чистой нравственности», «Сто тысяч реализаций великого собрания развития благого», «Черный бум о болезнях», «Пестрый бум о жизни», «Белый бум о лечении», «Черный бум о [ритуалах] To» [LXI] и др.

Раздел [различных] деяний: «360 методов То», «84000 методов исследования», «Четыре созерцания с чтением», «Восемь шепотов», «360 методов некромантии», «81 метод похорон» [LXII] и др.

Это называется «Боном мирской традиции черной воды» [LXIII].

В разделе порождения, завершения и плода: «Сокровищница Бон собранного вообще», «Собрание девяти свирепых отцовских тантр», «Явление девяти солнц материнской тантры», «Колоссальные сутры и тантры гневных [божеств]» [LXIV] и т. д. Это называют «Боном Мантры - белой воды» [LXV].

В разделе защиты [LXVI]: «Большой и малый напильники жизни», «Темнокрасная бритва иллюзий», «Реализация крови [духа] мамо обширного покоя» [LVII] и т. д.

Раздел реализации: [тексты, объясняющие реализацию разных духов -] посланцев мар, царей, цэнов, му, нагов, планет, могущественных [LXVIII] и т. д.

Раздел девяти колес животных [LXIX]. Раздел [магических] насыланий [LXX]. Раздел «Року шагпа чан гьюг тэн» [LXXI] и др.

В этих текстах говорится о непостоянстве, законе кармы, любви, сострадании, мысли о Просветлении (бодхичитте), шести парамитах и т. д., представлены также концепции пяти Путей, [или этапов пути совершенствования,] 10 ступеней [святости], трех Тел [достигшего конечного плода] и т. д. Есть много аналогов [буддийских текстов, касающихся] посвящения (абхишеки), [стадий] Рождения и Завершения, принятия обетов, освящения, жертвы сжиганием, реализации мандала и жертвы, похоронных обрядов и т. д., а также второстепенных ритуалов.

По форме имеется некоторое сходство с Учением Будды, но есть и кое-какие отличия. Так, Будда фигурирует как ешен и шенраг, Дхармакая - бонку, большой Юм - сатриэсан, Самбхогакая - кюнту санпо, Нирманакая - сридпа санпо, Архат - шенсрэ, Бодхисаттва - юндрун семпа, Учитель - пёнсэ, пустотность - амэнид, 10 ступеней: [ступень] Непорочная - ступень хрустальная, [ступень] Распространяющая свет - ступень массы облаков обладания ведением, ступень трансформации мyдpbl [LXXII] и т. д. Поэтому в употреблении терминов и наименований являют много своего.

4. Воззрения Бона в отношении взгляда, созерцуания и т. д.

Вообще признают, что Бон имеет два [вида] - внешний Бон и внутренний Бон [LXXIII]. В неком бонском тексте сказано:

Вначале - пустота, начальное небытие.

Затем - существование некоторого начального бытия.

Потом - существование подобного беловатому инею.

После этого - существование подобного появившейся росе - и т. д. 
В конце все «сосуды и соки» [LXXIV] рождаются из яйца. [Это - одна] система. Согласно другой, [все] создается судьбой, [богом] Ишварой и т. д. Дигун Чжигтэн Гёнпо [LXXV] говорит: «Является ошибочным воззрением тиртиков (брахманистов)». В получивших сейчас большое распространение ритуалах To [LXXVI] есть много сходного с приведенным выше.

А также, в бонском тексте «Тантра драгоценного собрания» [LXXVII] говорится:

Поскольку в относительном плане вещи признаются, то [они] существуют.

Поскольку в абсолютном плане [их] возникновение отвергается, то

[они] не существуют.

Поскольку ведает оба [эти моменты] беспристрастно и без отвлечений, то

Называется мудростью, [ведающей] пустотность (шуньяту).

Именно то является предметом созерцания

Во всеохватывающей [сфере] безмыслия, ясности и чистоты.

Если практикуют, сочетая два подобных [предмета] - взгляд и созерцание, то

В этом самом рождении обязательно обретут плод - освобождение.

Чен-а Лодой Гьялсан [LXXVIII] говорит об этом: «Представляется похожим на содержащееся в Слове [Будды] и трактатах [его последователей]». Кюнкьен Шервё и Таг Лоцава [LXXIX] тоже констатируют, что девятая Колесница Бона соответствует Зогчену Нинмапы.

В одном просмотренном мной бонском тексте излагается следующее. Прежде [появления] двух [видов индивидов] - Будд и живых существ [LXXX] - [имеется] Ясный свет, пустотность, Тело Бон (Бонку), сущность, [обладающая] совершенно чистой природой, не закрытой «покровом отпечатков» [LXXXI]. [Эта сущность] не является чем-то [определенным], но проясняет [LXXXII] нечто. Пребывает изначально как сущность Будды, не имеет места по причине деяния (кармы), не зависит от условия-действия, существует самостоятельно, без усилий, чудесно.

Поскольку благодаря ее постижению не становятся хорошими, а из-за неведения [ее] не становятся плохими, то [она] имеется у Будды и живого существа, не [являясь] у двух этих хорошим [или] плохим. Существует как всепронизывающая с колоссальным охватом. [Именно она является] фундаментальным принципом пребывания [LXXXIII]. Из нее чудесным образом возникает все сансарное и нирванистическое. Все дхармы пребывают в ее сфере. Ее сила проявляется непрерывно. Если постигнута, то является как мудрость. Если не постигнута, то является как деяние (карма) и клеша. Если уясняют, сокрушая тот предмет (карму или клеши), то постигается принцип пребывания базового состояния [LXXXIV]. Если она постигнута, то сама собой возникает в собственном потоке [бытия постигшего]. Когда она возникает, то обретается плод - реализуются три Тела [Будды].

Сущность того принципа пребывания не закрыта, обнажена, ясная-преясная. Обнаженному ведению, не загрязненному изучением, исследованием, активностью и усилием, является как мудрость. Тогда [та мудрость], взирающая в непамятовании, завершенная в ненаправленности, обнаженная в недискурсивности, всматривающаяся в невосприятии, называется самовозникшей мудростью ведения [LXXXV]. Целостное видение этого называется «взглядом».

Созерцание [состоит в следующем]. В середине дворца Драгоценного Ума, находящегося на восьмилепестковом [лотосе в сердечном] центре, пребывают пять Данма [LXXXVI]. В середине у них - пять мудростей, похожих на клубки цветной шерсти, а в центре находится световое яйцо - Тело Бон. Поскольку оно лишено сущности, то не относится к постоянному. Поскольку [оно] ведающее и ясное-проясняющее, то не относится к прерывающемуся [LXXXVII]. Не воспринимается как нечто. Его сила в трех лучах света являет три «двери», шесть собраний, шесть объ- 
ектов [LXXXVIII]. Когда рассматривают эту сущность целостно, без подразделения на два - рассматриваемое и рассматривающего, и устанавливаются в ясном осознавании [ее] без отвлечений и отделений, то, говорят, [это и] будет созерцанием.

Если подразделять [созерцание], то есть три [вида]: созерцание периодическое, созерцание естественное, созерцание средоточия [LXXXIX].

Первое - это созерцание, [которым занимаются] после ознакомления [с методом и которое] распределяют по периодам. Сначала пребывают [в созерцании] немного. В середине периоды [пребывания и непребывания в созерцании] одинаковы. В конце целиком уходят в сферу самадхи. Если устанавливаются в этом, то пребывают. Если оставляют, то выходят [из созерцания]. Если берутся [снова], то реализуют. Если могут [пребывать в самадхи] столько, сколько нужно, то это является критерием [реализованности] «периодического созерцания».

Второе. На некоем этапе возникает переживание самоосвобождения [XC]. Поскольку тогда нет вхождения в самадхи или выхода [из него], то возникает пребывание в несозерцании и неотвлечении. Это и является критерием реализованности «естественного созерцания».

Третье. Когда благодаря такому переживанию подобного ведения проясняется данность и уходят от [представлений] о созерцаемом и созерцающем, то выходят за пределы воспринимающего концептуально ума и возникает нечто подобное сущности пространства. Именно тогда все клеши являются как мудрость, все явления постигаются как совершенно чистая сфера Бон. Сансара и Нирвана, хорошее и плохое, подлежащее отвержению и принятию становятся одним нераздельным, реализуется собственная ступень Тела Бон, вследствие чего «созерцание средоточия» переходит на ступень исчерпания.

Поскольку по форме это похоже на излагаемое в системе Зогчена, то Бон и Зогчен одинаково [полагают] существование успокоенности внутри ума [XCI].

Бонские тексты прямо называют девять ступеней Колесниц [XCII]. Четыре Колесницы причины: шен предсказания, шен явления, шен волшебства, шен (мирского) существования [XCIII]. Четыре Колесницы плода: мирянин, белое «А», мудрец (санскр. риши), изначальный шен [XCIV]. И одна - особо великая Колесница [XCV]. [Всего] девять.

В шен предсказания - 360 То и 84000 исследований [XCVI]. В шен явления - четыре созерцания с чтением, восемь шепотов, 42 тараг [XCVII]. В шене волшебства - тексты о взгляде, очищении и волшебных силах (санскр. риддхи) [XCVIII]. В шен (мирского) существования 360 методов похорон, четыре двери кладбища, 81 метод усмирения [XCIX].

В [Колеснице] мирянина - разделы Сутр о возникновении и завершении «сосуда и сока» и т. д. В [Колеснице] мудреца - четыре раздела стотысячных [C]. $\mathrm{B}$ [Колеснице] белого «А» есть много тантрийских агама [CI]. В изначальном шене - четыре раздела читта-агама [CII]. В особой [Колеснице] есть четыре раздела практических указаний (санскр. упадеша).

[Благодаря] четырем [Колесницам] Бона причины избавляются от четырех представлений о воспринимаемом и воспринимающем [CIII]. [Колесницы] мирянина и мудреца очищают от «покрова клеш», а [Колесницы] белого «А» и изначального шен очищают от «покрова познаваемого» [CIV]. Великая особая искореняет врожденное [CV].

Говорится также: «Благодаря практике четырех [Колесниц] Бона причины в течение многих кальп обретают четыре ступени “действующего с верой” [CVI]. Одолев за три асанкхья [CVII] кальпы путь посредством [Колесниц] мирянина и мудреца, обретают освобождение. Благодаря [Колесницам] белого “А” и изначального шен освобождение обретается за одно рождение. Благодаря великой особой обретают Тело Бон за одну жизнь». 
Поскольку не обнаружил текста, подробно объясняющего, как развивался [и распространялся] Бон и [каковы] доктрины [этой системы], то его историю в Тибете изложил только по «Дигуне» [CVIII], а воззрения в отношении взгляда, созерцания и т. д. - по «Украшению солнечного света, освещающему узкую тропу в замок сокровенной Мантры», [содержащему] 84000 дверей Бон, [которые объяснили] все видьядхары и мудрецы Персии, Индии, Китая, Тибета и т. д., собравшиеся в тайной пещере Бон» [CIX].

\section{5. Бонские монастыри}

В Тибете [они были в] Шен Дар Дине, Юндрун Лхадине, что в Гьялмороне $[\mathrm{CX}]$, и т. д. В последующие времена [они] были разрушены войсками китайского императора. В Лхадине был возведен новый монастырь - гелугпинский, названный Гэндэном. Хотя и был издан указ о запрещении системы Бон, но и в настоящее время есть бонские центры [CI] в Гьялмороне, Цахо [CXII] и т. д.

Хотя и имеются основания говорить о несовместимости Учения [Будды] и Бон,

Но поскольку к Учению примешивается Бон, а к Бону примешивается Учение, то

[Как] подобный мне, не обладающий чистыми глазами Учения,

Достигнет успеха в разделении Учения и Бон?

Хотя и порицают Бон, но в серьезных случаях

Вопрошают у бонских гадателей, [что следует] принимать и отвергать.

Нравится читать напевом бонским. Очень надеются, что будет польза

От [ритуалов] То и других бонских методов исправления [ситуации].

Находится ли время для раздумий и соответствующих деяний

В этой наполненной множеством событий жизни?

Никто не занимается созерцанием дхьяны,

Когда выпадает свободный часок.

Если не так уж и много дел, если не так уж и много

Тем для разговоров, то ведите беседы об Учении.

Если не так уж и много предметов, требующих обдумывания,

Если не так уж и много требуется суетиться в заботах о хлебе насущном,

то уходите в уединение.

Эта беседа не является религиозной, не является мирской,

Не является необходимой, не является не необходимой,

Не является подробной, не является краткой,

Не является ясной, не является неясной.

Закончено повествование об истории системы Бон из «Хрустального зерцала, являющего происхождение и воззрения всех религиозно-философских систем».

Работа подготовлена в рамках государственного задания (проект «Трансформаџия направлений и школ буддизма: история и опьт взаимодействия с религиями и верованиями России, Центральной и Восточной Азии с периода распространения буддизма до современности (Россия - XVIII-XXI вв.; Китай - II-XXI вв.; Тибет - VII-XXI вв.; Монголия - XVIXXI вв.)») № 121031000241-1.

\section{Примечание}

I. Полное имя - Шенраб Мивоче (тиб. gshen rab mi bo che, совершенный жрец, великий человек). Считается основателем Бона или одним из его проповедников. Точное время жизни не установлено.

II. Тиб. dam pa'i chos. Так обычно называют свое учение буддисты.

III. Согласно буддийским представлениям, в тот огромный период времени (кальпу), который наступает после возникновения мира и появления человека, продолжительность жизни людей сначала постепенно сокращается от неисчислимого числа лет до 10 , а затем 
снова начинает расти и т. д. В настоящее время, по мнению буддистов, продолжительность жизни человека составляет 100 лет. Однако из-за болезней и других причин «несвоевременной смерти» большинство людей не доживает до этих лет, в то время как некоторые - вследствие наличия особой кармы - живут дольше.

IV. Тиб. Kun bzang (санскр. самантабхадра). Согласно некоторым бонпо, первым Учителем Бона был «Учитель-Бонку» (бонская Дхармакая) - Кюнсан, который объяснял путь освобождения. После него был «Учитель-Самбхогакая» - Шенлха Одгар (тиб. gshen lha od dkar, жрец - бог белый свет), излагавший Учение тайной Тантры. А Шенраб Мивоче является «Учителем-Нирманакаей», разъяснявшим «сторону Сутры» (аналог Парамитаяны) [Лобсан Тинлей 2002: 1462].

V. Тиб. Thang ma me sgron.

VI. Тиб. Zhang zhung gi yul gyi 'ol mo lung ring. Полагают, что это Элам (Олмо) в Персии [Кузнецов 2001: 66]. Отцом Шенраба называют царя Тогара (тиб. thod dkar), а матерью Йочи Гьялшэму (тиб. уо phyi rgyal bzhad ma) [Лобсан Тинлей 2002: 1462].

VII. rNam 'phrul.

VIII. Сочинение Сангье Гьяцо (sangs rgyas rgya mtsho, 1653-1705), знаменитого ученого и политика, регента (sde srid,) при V Далай-ламе.

IX. Термин «бон» считается производным от глагола «бон-па» (тиб. bon ра, «читать наизусть [молитвы, гимны]») и толкуется последователями Бон как «бог», «жрец» [Кузнецов 1998: 190], а также употребляется как аналог буддийской Дхармы (Учения) [Лобсан Тинлей 2002: 1462].

X. Тиб. gYung drung (свастика, счастье). Полностью сформировавшуюся систему Бон называют «юндрун-Бон», где слово «юндрун» указывает на неизменность, постоянство и прочность учения Бон [Там же].

ХI. Тиб. 'On mda' gser khang rtse zhes da lta mnga' ris grva tshang.

XII. Тиб. Rin chen spungs pa. По мнению Б. И. Кузнецова, Ринчен Пунпа - это Финикия [Кузнецов 2001: 23, 40]. Однако в данном случае, вероятно, имеется в виду упоминаемая Гой-лоцавой скала Ринчен Пунпа, расположенная неподалеку от долины Пагмоди [Гойлоцава 2001: 303].

XIII. Тиб. Kong yul bu chu lha khang gi shar phyogs bon ri. «Конпо» - название области, расположенной к юго-востоку от Лхасы. Страной Кон называют область, в которую переселились с юга «обезьяноносые» (spre sna) предки тибетцев [Лобсан Тинлей 2002: 102]. «Бучу» - один из главных монастырей в Конпо [Гой-лоцава 2001: 163].

XIV. Тиб. gYung drung gi chos phung sgo bzhi mdzod lnga. Четыре раздела Бона и пятый - сокровищница (бонская версия учения дзогчен) упоминаются в бонских текстах VIII в. [Кузнецов 2001: 31-32].

XV. Тиб. gDung 'tso ba mu tsho ldem drug. Это, вероятно, Дунсоб Мучо (тиб. gdung sob mu cho) из Тонтайнья (тиб. ston tha'i nуa) - один из выдающихся Учителей Бон [Там же 1998: 138-139]. С. Ч. Дас полагает, что здесь имеются в виду шестеро наставников, которые носили имена Мучо и Дэм [Das 1881: 196]. Однако Дж. Рейнольдс говорит о Мучо Демчуге как об апостоле Шенраба и называет шесть первых из перечисляемых далее Учителей Бон шестью «украшениями мира», известными учеными, которые сделали переводы Учения Бон на разные языки и распространили его по всему миру [Рейнольдс 1996: 43].

XVI. Тиб. Ta zig gi mkhas pa mu tsu tra hese, khri tog bar tsam, 'gu hi li spar ma. «Тасиг»одно из тибетских наименований Персии.

XVII. Тиб. Zha bdag sngags dro, legs tang smangs pa.

XVIII. Тиб. Khrom gyi mkhas pa gser rngog lce 'byams. По мнению Б. И. Кузнецова, это Хризостом - ритор, знаменитый деятель митраизма времен императора Трояна (I-IIв. н. э.). Страна Том (тиб. khrom) - Рим [2001: 77].

XIX. Тиб. Ldem gyin tsha smad dge.

XX. Тиб. Mi nyag gi mkhas pa lce tsha gar dgu. «Миньяг»- название области в Сикане (Кхаме), а также именование тангутов.

XXI. Тиб. Bum pa'i mkhas pa mu spungs gsang tang.

XXII. Тиб. Sha ra bu chen.

XXIII. Тиб. brDol bon, 'khyar bon, bsgyur bon. Это классификация буддийских ученых, которую сами бонпо не принимают [Лобсан Тинлей 2002: 1463]. 
XXIV. Тиб. gNya khri btsan po. Он обычно считается основателем древней династии тибетских царей. В датировке времени его жизни тибетскими учеными существует большой разнобой [Лобсан Тинлей 2002: хронол. табл.]. Шестой царь чаще фигурирует под именем Дагти (gdags khri) [Будон 1999: 247].

XXV. Тиб. Shod lon. «Уй»-dbus.

XXVI. Тиб. gSol mchod.

XXVII. Тиб. Yas stag.

XXVIII. Тиб. Khri thog rje btsan. Будон называет двадцать шестым не его, а следующего за ним царя Лха Тотори, во времена которого, согласно легенде, с неба спустился ларец с буддийскими текстами и ступой [Там же: 248].

XXIX. Тиб. Mar 'dre sri gnon, yar rgan gyi lha mchod pa, bar khyim gyi thab 'don. «Дре» - плохие, вредящие духи. «Сри» - духи умерших. «Божества» - хорошие духи «Боги-дре» (тиб. lha 'dre) - духи, которые могут как вредить, так и приносить пользу.

XXX. Тиб. Gri gum btsan po. Его считают восьмым в династии [Гой-лоцава 2001: 44], а время его жизни относят к первым векам нашей эры [Кузнецов 2001: 10, 31].

XXXI. Тиб. rGyu'i bon chab nag. Полагают, что этот черный Бон включает четыре из «12 знаний» Бона и открыто враждебен буддизму [Там же].

XXXII. Тиб. Gri bshid (нож-мертвец). Название похоронных обрядов, совершаемых по смерти убитого ножом для предотвращения всяческого вреда. Этот царь был убит ножом.

XXXIII. Это, по мнению Р. Н. Дугарова, Гильгит [Дугаров 2001: 57]. Эту страну упоминает и V Далай-лама в своей хронике [Кузнецов 1998: 269]. Возможно, имеется в виду область Аша (Гурнаватра), расположенная у границ Ирана и Индии.

XXXIV. Тиб. Ge gong khyud. Или гегонкьюн (тиб. ge gong khyung) [Лобсан Тинлей 2002: 1463]. Возможно, имеется в виду волшебная птица гаруда [Дугаров 2001: 57].

XXXV. Тиб. gTar ba len pa. По другому варианту [Лобсан Тинлей 2002: 464], находил потерянные (stor ba len pa) вещи.

XXXVI. Тиб. Ju tig, lha bka', sog dmar. С. Ч. Дас считает, что sog dmar (красная лопатка) - это свежая человеческая лопатка [Das 1881: 198]. Но в работах других исследователей фигурирует баранья лопатка, а слово «красная» толкуют как «обожженная» [Дугаров 2001: 57].

XXXVII. Тиб. gShin po 'dur ba. Похоронные, или кладбищенские, обряды.

XXXVIII. Тиб. Gri ‘dul ba (обуздание ножа). В Тибете считали, что душа (тиб. bla srog) убитого ножом (мечом) человека уносится злым духом, который вызывает смерть членов семьи убитого и других людей в данной местности. Для предотвращения этого делали обряд дидулва-усмирение того духа шедре (тиб. gshed 'dre) [Лобсан Тинлей 2002: 560]. Аналогичные обряды против шедре есть и в буддизме.

XXXIX. Тиб. bShid, или shid (мертвец, труп).

XL. Тиб. Mu stegs dbang phyug pa. Поскольку воззрения этой системы буддисты считали ошибочными, то и Бон, позаимствовавший эти взгляды, здесь называется ошибочным (тиб. 'khyar).

XLI. Тиб. Sham thabs sngon po can (имеющий синюю юбку). С. Ч. Дас указывает, что это некий индийский пандита, который за разглашение тайного и аморальное поведение был изгнан из своей конгрегации. Придя на север Кашмира, он выдавал себя за великого учителя. Написал несколько еретических книг, которые спрятал под землей, а затем при стечении публики «обнаружил» и признал древними текстами [Das 1881: 198].

XLII. Tep (gter), или терма (gter ma). Имеется в виду обычай прятать тексты в «кладах», чтобы уберечь и сохранить на будущие времена.

XLIII. Тиб. Khri srong lde btsan (755-788 или 797).

XLIV. Тиб. Rin chen mchog. То есть Учение о Трех Драгоценностях (Будде, Учении и Общине). Однако возможно, что Ринченчог - это тибетец из Ма, который в числе первых семи тибетцев стал монахом [Будон 1999: 252]. Следует отметить, что это место тибетского текста не отличается особой ясностью. Так, С. Ч. Дас полагает, что речь здесь идет о следующем. Царский министр Гьялвэ Чанчуб («Просветление Победителя») приказал бонскому жрецу Ринченчогу принять буддизм. Но тот не захотел. Будучи наказан за это царем, он пришел в ярость и вместе с другим бонпо тайно составил тексты, занимаясь плагиатом из буддийских канонических книг, за что он впоследствии был казнен [Das 1881: 199].

XLV. Тиб. Bon gter ma. 
XLVI. Тиб. Glang dar ma. Он воцарился после убийства царя Ралпачана в 839 г. и за девять лет практически уничтожил буддизм в Тибете [Кузнецов 1998: 319].

XLVII. Тиб. gShen rgur klu dga'. О нем см. в: [Там же: 149-153].

XLVIII. Тиб. gTsang nyang stod (Верхний Ньян в Цзане).

XLIX. Тиб. Dar yul sgro lag («Рука - перо» в стране Дар).

L. Сутра Праджня-парамиты объемом в 100 тыс. шлок (одна шлока содержит 32 слога).

LI. Тиб. Kham chen (большой кусок).

LII. Тиб. Kham chung (маленький кусок).

LIII. Тиб. gTan la dbab pa. Вероятно, это «Упадеша» - один из 12 разделов канона Будды.

LIV. Тиб. Bon mdo (сутры Бон).

LV. Тиб. gZungs sde lnga. Возможно, это «Паньчаракша».

LVI. Тиб. Klu 'bum dkar nag (белый и черный «Сто тысяч нагов»). У буддистов тоже есть «Лубум» (белый, черный, пестрый), авторство которого приписывается Нагарджуне.

LVII. Тиб. mTsho lnga ‘dre’u chung gi brag (скала маленького духа пяти озер).

LVIII. Тиб. 'Bras bu'i bon chab dkar.

LIX. Тиб. rDzogs pa rin chen gser gyi phreng ba, rtsa 'brel rlung gi spu gri, man ngag 'khor lo 'od gsal.

LX. Тиб. Phung po rang 'gyur thig le dgu skor, gser thig, lus sems nyams myong, sems lung ye khri dkar po.

LXI. Тиб. Khams bryad gtan la phab pa'i 'bum, ye gshen bkod pa don gyi 'bum, gyung drung sa bcu lam gyi 'bum, rnam dag tshul khrims 'dul ba'i 'bum, dge rgyas tshogs chen rdzogs pa'i 'bum, nad 'bum nag po, tshe 'bum khra bo, sman 'bum dkar po, gto 'bum nag po.

LXII. Тиб. gTo thabs sum brgya drug cu, dpyad thabs brgyad khri bzhi stong, gyer sgom bzhi, skad cong brgyad, shid thabs sum brgya drug cu, "dur thabs brgyad cu rtsa gcig.

LXIII. Тиб. Chab nag srid pa rgyud kyi bon.

LXIV. Тиб. sPyi spungs bon mdzod, pha rgyud drag po dgu 'dus, ma rgyud nyi ma dgu shar, khro rgyud mdo chen 'byams pa.

LXV. Тиб. Chab dkar sngags kyi bon.

LXVI. Тиб. Srung ma.

LXVII. Тиб. Srog gi sag gdar che chung, dra ba spu gri dmar nag, dal 'byams ma mo'i khram sgrub.

LXVIII. Тиб. Pho nya bdud, rgyal po, btsan, dmu, klu, gza', dbang phyug.

LXIX. Тиб. Byol song 'khor lo dgu.

LXX. Тиб. gTad. Этот термин обычно обозначает «насылание» разных бед и т. д.

LXXI. Тиб. Ro ku shag pa spyang rgyug than (труп, крик, комната, волк-бегун, дурной). Говорят, что бонпо показали Ю. Н. Рериху 140 томов своего Ганжура и 150 томов Данжура [Он же 2001: 12].

LXXII. Тиб. Ye gshen (изначальный жрец), gshen rag, bon sku (тело бон), sa tri e sang, kun tu bzang po (самантабхадра, всеблагой), srid pa sang po (имеющий чистое существование), gshen sras (сын шена), gyung drung sems dpa' ([обладающий] героической мыслью [о реализации] счастья), dpon gsas, 'a me nyid, shel gyi sa, rig 'dzin sprin phung gi sa, phyag rgya bsgyur ba'i sa.

LXXIII. Тиб. Phyi bon, nang bon.

LXXIV. Тиб. sNod bcud. Неодушевленное (сосуд) и одушевленное (сок).

LXXV. Тиб. 'Bri gung 'jig rten mgon (1143-1217). Основал в 1179 г. монастырь Дигун (тиб. 'bri gung) [Лобсан Тинлей 2002: 1557].

LXXVI. Тиб. gTo chog.

LXXVII. Тиб. 'Dus pa rin po che'i rgyud (gser mig). Это переведенная с шаншунского языка биография Шенраба, которая во время гонений на Бон при царе Тисрон Дэцэне была спрятана на кладбище в Самье (в 753 г.), а затем через 144 года извлечена бонцем Сермигом (тиб. gser mig) [Кузнецов 2001: 86].

LXXVIII. Тиб. sPyang snga blo gros rgyal bzang (1402-1472).

LXXIX. Тиб. Kun mkhyen sher od, stag lo tsa ba (р. в 1405 г.).

LXXX. Согласно философским воззрениям буддистов Тибета, индивид (тиб. gang zag) определяется как «обладающий жизнью». Индивидов подразделяют на два вида - Будд и живых существ (тиб. sems can, обладатель сознания) с точки зрения наличия элемента 
«сознания»: у Будды нет сознания и психических элементов, а у живых существ они есть [Агван Нима 1971: 134].

LXXXI. Тиб. Bag chags sgrib pa. Клеши (как семена) и карма существуют в виде «отпечатков» (санскр. васана) в сознании. Они образуют «покров» (санскр. аварана), который закрывает чистую природу сущего (как облако небо).

LXXXII. Тиб. gSal. Делает явленным, видимым, воспринимаемым.

LXXXIII. Тиб. gZhi'i gnas lugs.

LXXXIV. Тиб. gZhi'i gnas.

LXXXV. Тиб. Rang byung rig pa'i ye shes.

LXXXVI. Тиб. Dvangs ma (чистый сок, семя).

LXXXVII. Постоянство (тиб. rtag) и прерывность (тиб. chad) в буддизме считаются «крайностями» (тиб. mtha'), в терминах которых сущее не определяется. Ведание и ясность - прояснение (тиб. rig gsal) считаются характерными признаками психического, сознания, познания (тиб. shes pa).

LXXXVIII. Три «двери» (деяния) - тело, речь и ум. «Шесть собраний» - шесть видов сознания: сознание видимого глазом, слышимого ухом, обоняемого носом, вкушаемого языком, ощущаемого телом, мыслимого умом. «Шесть объектов» - объекты пяти органов чувств и ума.

LXXXIX. Тиб. Thun sgom, ngang sgom, klong sgom.

XC. Тиб. Rang grol gyi nyams. Переживание того, что возникающие явления сами собой «утихомириваются» и «уходят» в свое естественное состояние (тиб. rang gnas) пустотности.

XCI. Тиб. Thugs nang gshin po yod 'dra.

XCII. Тиб. Theg pa rim dgu.

XCIII. Тиб. rGyu'i theg pa bzhi: phyva gshen, snang gshen, 'phrul gshen, srid gshen. Первая содержит астрологию, вторая (путь видимого мира) - описание происхождения и природы божеств, ритуалов защиты, третья (путь магической силы) - объяснение методов устранения враждебных сил, четвертая (путь бытия) - описание похоронных обрядов и промежуточного состояния (бардо) [Кузнецов 2001: 31].

XCIV. Тиб. 'Bras bu'i theg pa bzhi: dge bsnyen (упасака), a dkar, drang srong, ye gshen. Первая содержит описание правил поведения мирян, 10 добродетелей и 10 совершенств, вторая - йоги звука «А» (высшей тантрийской практики), третья - пути монашества, четвертая - изначального шен [Там же].

$\mathrm{XCV}$. Тиб. Khyad par chen po'i theg ра. Содержит описание практики Зогчен.

XCVI. Тиб. gTo, dpyad.

XCVII. Тиб. Gyer sgom, skad cong, gta' rag.

XCVIII. Тиб. ITa byang rdzu 'phrul gyi gzhung.

ХCIX. Тиб. Shid thabs, 'dur sgo, 'dul thabs.

С. Тиб. 'Bum sde.

CI. Тиб. rGyud lung (объяснений тантры).

CII. Тиб. Sems lung (объяснений ума).

CIII. Тиб. gZung 'dzin gyi rtog cha bzhi. Очевидно, имеются в виду признания воспринимаемого и воспринимающего существующими субстанционально и условно.

CIV. «Покров клеш» (тиб. nyon sgrib) - главное препятствие обретению освобождения от сансары, а «покров познаваемого» (тиб. shes sgrib) - достижению положения Будды.

CV. Тиб. lHan skyes. Очевидно, имеются в виду врожденные формы «покрова познаваемого».

CVI. Тиб. Mos spyod kyi sa. «Действующим с верой» называют того, кто уже ступил на путь, но еще не обрел непосредственного видения абсолютного.

CVII. Тиб. Grangs med. Санскритское название числа 1059. «Кальпа» - большой период времени.

CVIII. Тиб. 'Bri gung dgongs gcig.

CVIX. Тиб. Yul mang mkhar gsang ba'i bon phug tu, stag gzig rgya dkar nag bod la sogs pa'i rig 'dzin mkhas pa mtha' dag 'dus nas, gsang sngags rdzong 'phrang nyi od rgyan bya ba.

CX. Тиб. gShen dar sding, rgyal mo rung du gyung drung lha sding.

CXI. Тиб. Bon sde.

CXII. Тиб. Tsha kho. 


\section{Иитература}

Агван Нима - Ngag dbang nyi ma. Nang pa'i grub mtha' bmra ba bzhi'i 'dod tshul ... (Bo3зрения четырех буддийских философских школ...). - sGo mang, 1971. - Ксил., 404 л.

Будон Ринчендуб. История буддизма (Индия и Тибет) / Ринчендуб Будон; пер. с тиб.

Е. Е. Обермиллера; пер. с англ. А. М. Донца. - СПб.: Евразия, 1999. - 336 с.

Гой-лоцава Шоннупэл. Синяя летопись / Шоннупэл Гой-лоцава; пер. с тиб. Ю. Н. Рериха; пер. с анг. О. В. Альбедиля и Е. Ю. Харьковой. - СПб.: Евразия, 2001. - 768 с.

Донеи А. М. Туган Лобсан Чокьи Нима. Хрустальное зерцало философских систем. Раздел «Философские системы буддийских школ Индии» (пер. с тиб. и коммент.) / А. М. Донец // Вестник Бурятского научного центра СО РАН. - 2021. - № 1. - С. 115-127.

Дугаров Р. Н. Бон и буддизм - парадигма буддийской цивилизации Тибета (IV-XIX вв.) / Р. Н. Дугаров. - Улан-Удэ: [б. и.], 2001. - 100 с.

Кузнеиов Б. И. Древний Иран и Тибет / Б. И. Кузнецов. - СПб.: Евразия, 1998. - 352 с.

Кузнецов Б. И. Бон и маздаизм / Б. И. Кузнецов. - СПб.: Евразия, 2001. - 224 с.

Лобсан Тинлей. mKhas dbang dung dkar blo bzang 'phrin las mchog gis mdzad pa'i bod rig pa'i tshig mdzog chen mo shes bya rab gsal zhes bya bzhugs so (Составленный владыкой мудрецов Дункар Лобсан Тинлеем большой словарь терминов тибетской науки «Полностью разъясняющий предметы познания») / Тинлей Лобсан. - Krung go'i bod rig pa dpe skrun khang, 2002. -2390 p.

Нестеркин С. П. Историко-философская традиция тибетского буддизма / С. П. Нестеркин // Вестник Бурятского научного центра СО РАН. - 2014. - № 4. - С. 10-16.

Рейнольдс Дж. Юндрун-бон - непресекаемая традиция / Дж. Рейнольдс // Гаруда. 1996. - № 2. - C. 35-43.

Das S. Ch. Contribution on the religion, history etc. of Tibet / S. Ch. Das // JASB. - 1881.Vol. L. - P. 187-245.

\section{References}

Agvan Nima - Ngag dbang nyi ma. Nang pa'i grub mtha' bmra ba bzhi'i 'dod tshul ... (Vozzreniya chetyrekh buddijskih filosofskih shkol...). - sGo mang, 1971. - Ksil., 4041.

Budon Rinchendub. Istoriya buddizma (Indiya i Tibet) / Rinchendub Budon; per. s tib. E. E. Obermillera; per. s angl. A. M. Donca. - SPb.: Evraziya, 1999. - 336 s.

Goj-locava Shonnupel. Sinyaya letopis' / Shonnupel Goj-locava; per. s tib. Yu. N. Reriha; per. s ang. O. V. Al'bedilya i E. Yu. Har'kovoj. - SPb.: Evraziya, 2001. - 768 s.

Donec A. M. Tugan Lobsan Chok'i Nima. Hrustal'noe zercalo filosofskih sistem. Razdel «Filosofskie sistemy buddijskih shkol Indii» (per. s tib. i komment.) / A. M. Donec // Vestnik Buryatskogo nauchnogo centra SO RAN. - 2021. - № 1. - S. 115-127.

Dugarov R. N. Bon i buddizm - paradigma buddijskoj civilizacii Tibeta (IV-XIX vv.) / R. N. Dugarov. - Ulan-Ude: [b. i.], 2001. - 100 c.

Kuznecov B. I. Drevnij Iran i Tibet / B. I. Kuznecov. - SPb.: Evraziya, 1998. - 352 s.

Kuznecov B. I. Bon i mazdaizm / B. I. Kuznecov. - SPb.: Evraziya, 2001. - 224 s.

Lobsan Tinlej. mKhas dbang dung dkar blo bzang 'phrin las mchog gis mdzad pa'i bod rig pa'i tshig mdzog chen mo shes bya rab gsal zhes bya bzhugs so (Sostavlennyj vladykoj mudrecov Dunkar Lobsan Tinleem bol'shoj slovar' terminov tibetskoj nauki «Polnost'yu raz”yasnyayushchij predmety poznaniya») / Tinlej Lobsan. - Krung go'i bod rig pa dpe skrun khang, 2002. - 2390 p.

Nesterkin S. P. Istoriko-filosofskaya tradiciya tibetskogo buddizma / S. P. Nesterkin // Vestnik Buryatskogo nauchnogo centra SO RAN. - 2014. - № 4. - S. 10-16.

Rejnol'ds Dzh. Yundrun-bon - nepresekaemaya tradiciya / Dzh. Rejnol'ds // Garuda. - 1996. - № 2. - S. 35-43.

Das S. Ch. Contribution on the religion, history etc. of Tibet / S. Ch. Das // JASB. - 1881.Vol. L. - P. 187-245. 